УДК 379.85(075.8)

\title{
ПОТЕНЦІАЛ УКРАЇНИ У КОНТЕКСТІ МІЖНАРОДНОГО ТУРИЗМУ
}

\section{POTENTIAL OF UKRAINE IN THE CONTEXT OF INTERNATIONAL TOURISM}

\author{
Краснодєд Тетяна Леонідівна \\ кандидат економічних наук, доцент, \\ Таврійський державний агротехнологічний університет \\ імені Дмитра Моторного \\ ORCID: https://orcid.org/0000-0002-8930-3248 \\ Попова Тетяна Вікторівна \\ кандидат економічних наук, доцент \\ Таврійський державний агротехнологічний університет \\ імені Дмитра Моторного \\ ORCID: https://orcid.org/0000-0001-6531-1422
}

\author{
Krasnoded Tatiana, Popova Tetiana \\ Tavria State Agrotechnical University named after Dmytro Motornyi
}

\begin{abstract}
Туристичний бізнес активно розвивається майже по всьому світу, тому питання розвитку туристичного потенціалу України і можливості забезпечення туристських потреб є актуальними. В статті здійснено огляд останніх досліджень в галузі світового туризму та освітлено пропоновані науковцями шляхи розвитку вітчизняного. Надано визначення туристичної дестинації як об'єкта дослідження. Виявлено об'єктивну необхідність огляду туристичного потенціалу України та охарактеризовано її основні природно-економічні туристичні ресурси. Проаналізовано зміну головних показників функціонування туріндустрії країни - кількість суб'єктів туристичної діяльності, їх витрати на виробництво турпродуктів, кількість та вартість реалізованих туристичних путівок, кількість відповідних туроднів, кількість туристів, обслугованих туроператорами та турагентами, а також завантаженість колективних засобів розміщування. Водночас проведено аналіз кількості туристів, які обслуговувались вітчизняними туроператорами та турагентами в залежності від мети подорожі. Запропоновано напрями удосконалення використання туристичного потенціалу України.

Ключові слова: міжнародний туризм, туристичні ресурси, туроператори, турагенти, туристичний продукт, туристична дестинація, засоби розміщення.
\end{abstract}

Туристический бизнес активно развивается почти по всему миру, поэтому вопросы развития туристического потенциала Украины и возможности обеспечения туристских потребностей актуальны. В статье сделан обзор последних исследований в области мирового туризма и освещены предлагаемые учеными пути развития отечественного. Дано определение туристической дестинации как объекта исследования. Выявлено объективную необходимость осмотра туристического потенциала Украины и охарактеризованы ее основные природно-экономические туристические ресурсы. Проанализировано изменение главных показателей функционирования туриндустрии страны - количество субъектов туристической деятельности, их затраты на производство турпродуктов, количество и стоимость реализованных туристических путевок, количество соответствующих туродней, количество туристов, обслуженных туроператорами и турагентами, а также загруженность коллективных средств размещения. В то же время проведен анализ количества туристов, которые обслуживались отечественными туроператорами и турагентами в зависимости от цели путешествия. Предложены направления совершенствования использования туристического потенциала Украины.

Ключевые слова: международный туризм, туристические ресурсы, туроператоры, турагенты, туристический продукт, туристическая дестинация, средства размещения.

The tourism industry and socio-cultural services are now successfully and rapidly developing worldwide. The growth rate of the main economic indicators of the development of tourism enterprises is comparatively high despite the current objective travel barriers. These trends are also typical for Ukraine. The country has all the natural and 
economic prerequisitesto develop tourism, primarily its domestic and inbound types. The availability of natural, recreational, historical, cultural, social and labour resources make for powerful tourism potential. Therefore, the study of economic issues of the tourism development, directions of tourist flows, and the capability of existingtourism enterprises to meet the needs of domestic and foreign tourists is an important area of research. Meanwhile, to assess the tourist potential of Ukraine, it is crucialto determine its position on the global market. The article reviews current research in global tourism and the ways to develop the domestic tourism industry. The results of research in several aspects of the tourist sector of Ukraine are presented. The definition of a tourist destination as an object of study isgiven, the objective need to review the tourist potential of the country is identified and the main tourist resources of Ukraine such as natural and climatic, historical, cultural and socio-economicare considered. The dynamics of the main indicators of the tourist industry in the country for the last several years are characterized. The most noticeable changesinclude the number of tourism entities, the production cost of tourist products, the number and cost of tourist vouchers sold by tour operators and travel agents, the number of tourists on tourist vouchers, the number of tourists served by tour operators and travel agents, and the occupancy and capacity of tourist accommodation. The dynamics and structure of the tourist flows served by domestic tour operators and travel agents depending on the purpose of travel are analysed. The article proposes directions and specific measures for the development of the domestic tourism industry, taking into account the natural, economic, historical and cultural potential of Ukraine.

Keywords: international tourism, tourist resources, touroperators, travel agents, tourist product, tourist destination, means of tourist accommodation.

Постановка проблеми. Туризм та туристична індустрія України на сучасному етапі розвивається помірними темпами. В більшості випадків змінні тенденції показників туристичної діяльності всіх суб'єктів вітчизняного ринку туристських послуг носять позитивний характер. Водночас існує ряд об'єктивних проблем та питань, що потребують ґрунтовного дослідження у зв'язку з наявними бар'єрами до подорожей та з метою формування ефрективної стратегії участі України на світовій туристській арені на правах конкурентоспроможної туристичної дестинації. Тому аналіз проблемних теоретико-практичних аспектів функціонування туристичної індустрії України в контексті покращення її туристичного майбутнього до рівня європейських країн $є$ актуальним та своєчасним.

Аналіз останніх досліджень і публікацій. Питаннями фрункціонування і розвитку туристичної індустрії, в тому числі і на регіональному рівні, 3 огляду на актуальність тематики, займається досить багато теоретиків та практиків. Актуальні проблеми в галузі вітчизняного туризму, обгрунтування ефективної стратегії розвитку туризму крізь призму наукових поглядів, світового досвіду, сучасних тенденцій розвитку та можливостей України на світовому ринку туристичних послуг висвітлено в дослідженнях таких авторів, як Кифяк В.Ф., Криховецький І.З., Мальська М.П., Бордун О.Ю., Марценюк Л.В., Школа І.М. та ін. [8; 10-13]. Водночас розвиток української туристичної галузі на засаді дослідження особливостей її існування з урахуванням аналізу головних фрорм та напрямів її розвитку, а також проблеми розвитку конкретних та загальних видів туристичної діяльності, її конкурентоспро- можності освітлено в працях Бортникова Є.Г., Гладкої І.В., Квартального В.А., Мацуки В.М., Фоміна Ю.В., Харічевої М.В. та ін. [1; 3; 14]. Результати дослідження фракторів розвитку туризму в країні та визначення їх впливу на обсяги надання туристичних послуг розкрито в роботах Комліченко О.О., Дядечко Л.П., Азаряна О.М., Жукової Н.Л., Жукової М.О. та ін. В результаті визначено вплив декількох груп постійних та змінних чинників впливу на розвиток туристичної індустрії - внутрішнього та зовнішнього середовища, ендогенних та екзогенних, позитивних і негативних, інвестиційних, інфрраструктурних, маркетингових тощо. [6; 9]. Серед російських вчених слід виділити досягнення Виноградової Т.В., Гуляєва В.Г., Ільїної О.М., Моісеєвої Н.К., Сеніна В.С. і Черевичко Т.В. Вони ґрунтовно розкривають стратегії управління і економічного розвитку галузі туризму і технології туроперейтингу [2; 4; 7].

Постановка завдання. Головною метою дослідження $€$ висвітлення окремих тенденцій розвитку сучасної туристичної індустрії України та обґрунтування ії̈ перспектив на ринку міжнародного туризму.

Виклад основного матеріалу дослідження. Україна - дуже приваблива країна 3 туристичної точки зору. Це пояснюється наявністю на її туристичних дестинаціях різноманітних туристичних ресурсів - природнорекреаційних, історико-культурних та соціально-економічних. Туристична дестинація являє собою певну географрічну територію в межах країни чи регіону, що характеризується особливим набором туристичних ресурсів.

Найголовнішим компонентом природнорекреаційних ресурсів країни $€$ курорти. За інформаційними даними науково-практич- 
ного довідника «Курорти та санаторії України» (Київ, 2009) перелік курортних дестинацій в Україні чималий: узбережжя Азовского моря; гірські та передгірські райони Закарпатської, Івано-Франківської та Львівської областей; курортні зони Вінницької, Донецької, Київської, Полтавської та Харківської областей; чорноморське узбережжя Миколаївської, Одеської та Херсонської областей та Узбережжя Криму. Водночас неоцінними $є$ бальнеологічні рекреації, повітря і кліматичні умови на площах українських лісів та гір. В теоретичних працях таких авторів, як М.П. Мальська, Н.В. Антонюк, Н.М. Ганич добре описуються історикокультурні туристичні ресурси України, до яких можна віднести численні пам'ятки історії та культури. Їх понад 70 тис. і сьогодні вони перебувають під охороною держави. Серед них понад 12 тис. особливо цінних у туристичному плані, оскільки вони які $є$ зразками монументальних витворів мистецтва, починаючи від 3 ст. до н. е. Більшість історико-культурних пам'яток розташовано в західних регіонах України, а також у Київській, Хмельницькій, Вінницькій, Чернігівській, Сумській областях та в Республіці Крим. Східні й південні області не е настільки багатими на пам'ятки архітектури. Найбільше пам'яток історії та архітектури розміщено у Львові (2500) та Львівській області. Другим містом в Україні за кількістю пам'яток архітектури $€$ Київ (понад 1500). Передусім це споруди епохи Київської Русі. Кам'янець-Подільський - місто-заповідник, що за кількістю пам'яток архітектури (понад 150) посідає третє місце в Україні. В Україні існують пам'ятки, що залишилися з часів колонізації Причорномор'я. Через регулярні напади на землі України іноземних загарбників на її території споруджено чимало замків і фортець, які мають європейське значення. До найцінніших варто віднести замки в Ужгороді, Кременці, Луцьку, Острозі та ін. [11]. Щодо соціально-економічних туристичних ресурсів України, то слід відмітити, що як туристична дестинація вона має вигідне географрічне положення, зручне транспортне сполучення і морські шляхи, достатню кількість працездатного населення, зайнятого в соціально-культурному сервісі та сорері туризму, наявну туристичну інфрраструктуру в межах туристичної індустрії. До того ж обслуговування туристів відбувається за міжнародними стандартами, а рівні добробуту та розвитку господарства в країні дозволяють приймати як вітчизняних, так і іноземних гостей на достойному рівні, що не використовується ефрективно та раціонально.
Туристична індустрії в Україні на сучасному етапі характеризується розвитком відповідних подій та зростанням більшості показників. Отже, в 2019 році в Україні фрункціонувало 4664 суб'єкта туристичної діяльності. До цієї цифрри входять як юридичні, так і фрізичні особи. Це туристичні агенти, туроператори, суб'єкти, що здійснюють екскурсійну діяльність та інші суб'єкти, що забезпечують фрункціонування соціально-культурного сервісу та туризму в країні. Зазначений показник на 34,4\% більше, ніж в 2017 році та майже на 9,0\%, ніж в попередньому 2018. 3 усіх суб'єктів туристичного бізнесу основну частину займають турагенти $83,7 \%$. Частка туроператорів практично в 7 разів менше. Це пояснюється тим, що до них відносяться лише юридичні особи. Щодо тенденції зміни їх кількості протягом 2017-2019 рр., то тут також можна відмітити щорічне зростання. Витрати суб'єктів туристичної діяльності на послуги сторонніх організацій, що використовуються при виробництві туристичного продукту в 2019 році становили 32404332,1 тис. грн. Це на 76,2\% більше, ніж в 2017 році та на 42,4\% порівняно з попереднім 2018 роком. Аналогічна тенденція спостерігалася з кількістю реалізованих туристичних путівок туроператорами і турагентами. Зростання за 2017-2019 рр. склало 113,2\%. При цьому вартість їх також відповідно зростала. Кількість туроднів за реалізованими туристичними путівками зросла більше, ніж в 1,5 рази. Темпи зростання кількості реалізованих турпродуктів не надто відрізняються від темпів зростання їх вартості. Це говорить про лояльну цінову політику вітчизняних туроператорів по відношенню до споживачів турпослуг.

Щорічне зростання вказаних показників говорить про невпинне зростання кількості туристів протягом аналізованого періоду, які обслуговувалися туроператорами та турагентами (без екскурсантів). Так, за два роки воно склало 220,5\%, що у натуральному виразі становить 6187869 осіб. У відповідності до такого зростання туристів в Україні останнім часом виникає потреба у нарощуванні кількості колективних засобів їх розміщування та харчування. Щорічне зростання кількості таких та інших інфрраструктурних об'єктів відбувалося помірними темпами. Наприклад, кількість колективних засобів розміщування туристів за 2017-2019 рр. зросла на 29,6\% і в 2019 році їх в Україні було вже 5335 од. Основна частина з них - це готелі та аналогічні засоби розміщення (59,3\%), інше - це різноманітні оздоровчі заклади, табори праці та відпочинку, громадські засоби транспорту, 
конгрес-центри, облаштовані житлові місця для відпочинку, площадки для кемпінгу тощо (40,7\%). Кількість туристів, що припадає на один колективний засіб розміщення в 2019 році становила 1686 осіб, що в 2,5 рази більше, ніж в 2017 році. Тому і кількість місць у колективних засобах розміщення туристів збільшується. За неофіційними даними таке положення можна в повній мірі віднести і до індивідуальних закладів розміщення туристів. Наприклад, це житло, яке орендується туристами у приватних осіб чи агентств, у сімейних будинках або житло, що надається безкоштовно родичам чи знайомим, власне житло в іншому місті, країні.

Переважну частину споживачів туристичного продукту, обслугованих туроператорами та турагентами, складають туристи, що мандрують 3 метою, відпочинку та гарного проведення дозвілля. Їх питома вага в загальній кількості туристів перевищує 90\%. I це цілком логічно з огляду на той фракт, що туризм по своїй сутності передбачає наявність у людини вільного часу, проведеного в мандрах із задоволенням, отримуючи фрізичну користь та цікаві туристські враження. На відміну від відпочивально-розважального туризму інші цільові види туризму, як правило, викликані об'єктивною необхідністю у людини до поїздки, тому не носять масовий характер. Це лікувальний, діловий, навчальний, спеціалізований туризм та інші. Саме тому їх масова доля у загальній кількості туристів набагато менше. Наприклад, питома вага ділового туризму трохи більше 5\%, а спортивного - не перевищує і 1\%. Водночас слід зазначити, що за останні три роки кількість туристів, обслугованих туроператорами та турагентами України, по кожному напрямку туризму зросла. Так, загальне зростання кількості туристів 3 2017 по 2019 рік на 118,5\% відбулося за рахунок збільшення кількості туристів відпочивально-розважального напрямку на $128,9 \%$, службового і навчального на 37,4\%, спортив- ного на 48,3\%, спеціалізовано аж на $778 \%$, а також зменшення кількості туристів з метою лікувальної поїздки на 16,9\%. Як видно, величезне зростання кількості туристів за три аналізовані роки відбулося по спеціалізованому напрямку туризму (екологічний, сільський, кулінарний, винний, фрестивальний, військовий, спелеотуризм тощо). Проте значного впливу на загальний показник зростання по країні це не здійснило, оскільки питома вага спеціалізованого туризму у всій кількості туристів становить всього 0,19\%. Інша річ вплив відпочивально-розважального туризму. Ймовірно в контексті саме його зростання відбулося і значне збільшення кількості подорожуючих дітей - в 2,7 рази за останні три роки.

Висновки. Молода туристична індустрія України сьогодні стрімко розвивається та має шанси на удосконалення 3 огляду на наявний туристичний потенціал, до якого відносять природно-рекреаційні, історико-культурні, соціально-економічні, нормативно-правові складові. Кількісні показники туристичної діяльності в країні свідчать про різноспрямованість тенденцій в галузі туризму та відповідно наявність певних проблемних аспектів. Наприклад, невисока зацікавленість іноземного туриста в подорожі до України або середній рівень розвитку туристичної інфрраструктури. За таких умов конкурентоспроможність українських туристичних дестинацій в якості об'єктів світового ринку туристських послуг є сумнівною, а основними видами туризму будуть залишатися виїзний та внутрішній. При цьому зовнішня торгівля основними туристськими послугами буде мати імпортозалежний вектор. На думку авторів, стратегічний розвиток вітчизняної туристичної індустрії в умовах глобалізації та конкурентоздатної участі на світовому ринку повинен корелювати, по-перше, 3 розвитком соціально-культурного сервісу на рівні європейського та, по-друге, з посиленням внутрішньої креативності головних суб'єктів, що створюють та надають туристські послуги.

\section{СПИСОК ВИКОРИСТАНИХ ДЖЕРЕЛ:}

1. Бортников Є.Г. Пріоритетні напрями розвитку туристичної галузі в Україні. Вісник ДІТБ. Серія : Економіка, організація та управління підприємствами туристичної індустрії та туристичної галузі в цілому. 2009. № 13. C. 157-163.

2. Виноградова Т.В., Закорин Н.Д., Тубелис Р.Ю. Технология продаж услуг туристской индустрии : учебник для вузов по специальности «Туризм» / Балт. акад. туризма и предпринимательства. Москва, 2010. 238 с.

3. Гладка І.В. Сучасні тенденції та особливості розвитку туризму в Україні. Економіка. Проблеми економічного становлення. 2015. Випуск 1-2. С. 64-67.

4. Гуляев В.Г. Туризм: экономика, управление, устойчивое развитие : учебник. Москва : Советский спорт, 2008. $280 \mathrm{c}$. 
5. Довідник КЗЕП 2012 / Класифрікація зовнішньоекономічних послуг 2012. URL: https://dovidnyk.in.ua/ directories/kzep-2012/04 (дата звернення: 26.02.2021).

6. Жукова М.А. Индустрия туризма: менеджмент организаций. Москва : Финансы и статистика, 2006. 200 с.

7. Ильина Е. Н. Туроперейтинг: организация деятельности : учеб. для вузов турист. профиляя / Рос. междунар. акад. туризма. 2-е изд., перераб. и доп. Москва : Финансы и статистика, 2008. 241 с.

8. Кифряк В.Ф. Організація туристичної діяльності в Україні. Чернівці : Книги-XXI, 2003. 300 с.

9. Компліченко О.О. Фактори розвитку туристичної галузі. Науковий вісник Херсонського державного університету. Серія : Економічні науки. 2014. Випуск 8. Частина 3. С. 75-79.

10. Криховецький І.3. Туристична індустрія України: стан, проблеми та перспективи розвитку. Науково-інсоормаційний вісник Івано-Франківського університету права ім. Короля Данила Галицького. 2011. № 3. С. 158-166.

11. Мальська М.П., Антонюк Н.В., Ганич Н.М. Міжнародний туризм і ссрера послуг : підручник. Київ : Знання, 2008. $661 \mathrm{c.}$.

12. Мальська М.П., Бордун О.Ю. Організація та планування діяльності туристичних підприємств: теорія та практика : навч. посіб. Київ : Центр учбової літератури, 2012. 248 с.

13. Марценюк Л.В. Проблеми та перспективи розвитку туризму в Україні. Економічний вісник. Секція : Економічна теорія. 2015. № 3. С. 76-82.

14. Мацука В.М. Сучасні тенденції та перспективи розвитку туризму в Україні. Вісник Маріупольського державного університету. Серія : Економіка. 2011. Вип. 1. С. 43-49.

15. Опря А.Т. Статистика: (з програмованою фрормою контролю знань). Київ : Урожай, 1996. 448 с.

\section{REFERENCES:}

1. Bortnykov Ye.H. (2009) Priorytetni napriamy rozvytku turystychnoi haluzi v Ukraini [Priority directions of tourism industry development in Ukraine]. DITB Bulletin. Series: Economics, organization and management of enterprises in the tourism industry and the tourism sector in general, no. 13, pp. 157-163.

2. Vinogradova T.V. (2010) Tekhnologiya prodazh uslug turistskoy industrii: uchebnik dlya vuzov po spetsial'nosti «Turizm» [Technology of sales of services in the tourist industry: a textbook for high schools on a specialty "Tourism"]. Moscow: Baltic Academy of Tourism and Entrepreneurship. (in Russian)

3. Hladka I.V. (2015) Suchasni tendentsii ta osoblyvosti rozvytku turyzmu v Ukraini [Current trends and features of tourism development in Ukraine]. Economics. Problems of Economic Formation, no. 1-2, pp. 64-67.

4. Gulyayev V.G. (2008) Turizm: ekonomika, upravleniye, ustoychivoye razvitiye: uchebnik [Tourism: economics, management, sustainable development: a textbook]. Moscow: Soviet Sport. (in Russian)

5. Dovidnyk KZEP (2012) Klasyfikatsiia zovnishnoekonomichnykh posluh 2012 [Classification of Goods of Foreign Economic Activity 2012]. Available at: https://dovidnyk.in.ua/directories/kzep-2012/04

6. Zhukova M.A. (2006) Industriya turizma: menedzhment organizatsiy [Tourism industry: management of organizations]. Moscow: Finance and Statistics. (in Russian)

7. Il'ina YE.N. (2008) Turopereyting: organizatsiya deyatel'nosti: ucheb. dlya vuzov turist. profilya [Touring: organization of activity: a textbook for universities of a tourist profile]. Moscow: Finance and Statistics. (in Russian)

8. Kifyak V.F. (2003) Organizatsiyaturistichnoï diyal'nosti v Ukraini [Organization of tourist activity in Ukraine]. Chernivtsi: Books-XXI. (in Russian)

9. Komplichenko O.O. (2014) Faktory rozvytku turystychnoi haluzi [Factors of the tourism industry development]. Scientific Bulletin of Kherson State University. Series: Economic Sciences, vol. 8, no. 3, pp. 75-79.

10. Krykhovetskyi I.Z. (2011) Turystychna industriia Ukrainy: stan, problemy ta perspektyvy rozvytku [Tourism industry of Ukraine: state, problems and prospects of development]. Scientific and information Bulletin of Danylo Halytskyilvano - Frankivsk University of Law, no. 3, pp. 158-166.

11. Malska M.P. (2008) Mizhnarodnyi turyzm i sfera posluh: pidruchnyk [International tourism and services: a textbook]. Kyiv: Znannia. (in Ukrainian)

12. Malska M.P., Bordun O.Yu. (2012) Orhanizatsiia ta planuvannia diialnosti turystychnykh pidpryiemstv: teoriia ta praktyka: navch. posib. [Organization and planning of tourist enterprises: theory and practice: textbook]. Kyiv: Center for Educational Literature. (in Ukrainian)

13. Martseniuk L.V. (2015) Problemy ta perspektyvy rozvytku turyzmu v Ukraini [Problems and prospects of tourism development in Ukraine]. Economic Bulletin. Section: Economic Theory, no. 3, pp. 76-82.

14. Matsuka V.M. (2011) Suchasni tendentsii ta perspektyvy rozvytku turyzmu v Ukraini [Modern trends and prospects of tourism development in Ukraine]. Bulletin of Mariupol State University. Series: Economics, vol. 1, pp. 43-49.

15. Opria A.T. (1996) Statystyka: (z prohramovanoiu formoiu kontroliu znan) [Statistics: (with a programmed form of knowledge control)]. Kyiv: Urozhai. (in Ukrainian) 